Plant Tissue Cult. \& Biotech. 24(1): 125-129, 2014 (June)

$\overline{\text { PTC\&B }}$

\title{
Morphological and Physiological Characterization of Embryogenic and Non-embryogenic Tissues of Centella asiatica
}

\author{
Kok Song Lai ${ }^{*}$, Khatijah Yusoff ${ }^{1}$ and Maziah Mahmood ${ }^{2}$ \\ Agro-Biotechnology Institute Malaysia, Ministry of Science, Technology and Innovation, \\ Clo. MARDI Headquaters, 43400 Serdang, Selangor DE, Malaysia
}

Key words: Centella asiatica, Embryogenic cell, Non-embryogenic cell, Shoot organogenesis

Centella asiatica L. (Apiaceae) commonly known as 'Indian pennywort' or 'Mandukaparni' is an important medicinal plant. It is useful for the treatment of asthma, bronchitis, dropsy, hypertension, skin disease and urethritis (Lai et al. 2011, Lai et al. 2012). To date, regeneration of C. asiatica through somatic embryogenesis (Paramageetham et al. 2004) and organogenesis (Patra et al. 1998, Tiwari et al. 2000) have been reported. However, the morphological and physiological characteristics that defined the C. asiatica embryogenic cells remained largely unknown. Such information is crucial to allow a rapid identification of $C$. asiatica embryogenic cells for efficient clonal propagation. Here, we aimed to carry out a systematic comparison between $C$. asiatica embryogenic (CE) and non-embryogenic (CNE) cells by growth curve measurement, transmission electron microscopy (TEM), and shoot organogenesis efficiency analysis.

Young C. asiatica plants were collected from the Herbal Garden of the Institute Biosciences, University Putra Malaysia. The leaf explants were surface sterilized as described by Chandra et al. (2014) and used for callus induction on MS supplemented with $2 \mu \mathrm{M}$ 2,4-D and $1 \mu \mathrm{M}$ Kn grown under $16 \mathrm{hrs}$ photoperiod at $24 \pm 2^{\circ} \mathrm{C}$. The growth curve measurement of calli was monitored weekly by measuring their fresh and dry weight. Ultrastructural analyses of calli morphology were performed using TEM according to the method described by Namasivayam (2007). The effect of different optimized induction media on shoot

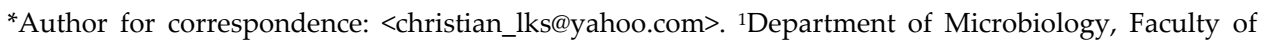
Biotechnology and Biomolecular Sciences, University Putra Malaysia (UPM), 43400 Serdang, Selangor DE, Malaysia. ${ }^{2}$ Department of Biochemistry, Faculty of Biotechnology and Biomolecular Sciences, University Putra Malaysia (UPM), 43400 Serdang, Selangor DE, Malaysia. 
organogenesis efficiency of the induced calli were also examined by supplementing the MS with different plant growth regulators as reported previously (Paramegeetham et al. 2004, Patra et al. 1998, Deshpande et al. 2010). Regenerated shoots were excised and cultured in the rooting half strength MS containing $0.5 \mu \mathrm{M}$ IAA. Rooted plantlets were then washed thoroughly to remove the adhering gel for greenhouse acclimation.

Two types of $C$. asiatica callus were successfully induced from the leaf explants. $\mathrm{CE}$ callus is greenish and compact in morphotype (Fig. 1A). In contrast, CNE callus is friable and pale yellowish in color (Fig. 1B). In order to understand the cell division and proliferation characteristics, we measured the growth curve of both CE and CNE cells. Both fresh and dry weight measurements of CE calli indicate a normal cell growth and proliferation pattern with initial, exponential, stationary and decline phases (Fig. 1C, D). The CNE calli showed a higher biomass with longer exponential phase and no defined decline phase, suggesting rapid and uncontrolled cell divisions (Fig. 1C, D). These CNE cells proliferate quickly and achieve the highest biomass cultures at 28 days with an average fresh weight of $21.67 \mathrm{~g}$ (Fig. 1C, D). Unlike greenish CE cells CNE cells begin to turn into brownish color at the third week of subculture, indicating the initiation of death of cells. Under TEM, CE cells showed smaller cell size and thicker cell walls as compared to CNE (Fig. 1E, F). These CE cells contain centrally located large nucleus with nucleolus, dense cytoplasm, and prominent organelles (Fig. 1E). The plastids also showed the presence of starch granules. Mitochondria were also abundant and appeared adjacent to the cell wall, suggesting active cell metabolism and differentiation (Fig. 1E). Collectively, the observed CE cells resemble the previously reported meristematic cells in the embryogenic tissue of Quercus suber L. (Puigderrajols et al. 2001), Brassica napus spp. oleifera (Namasivayam et al. 2006), and Actinidia deliciosa cv. Hayward (Marzena et al. 2006). Meanwhile, CNE cells become bigger, highly vacuolated containing numerous vesicles (Fig. 1F).

Although embryogenic tissue has been suggested to exhibit better regeneration efficiency as compared to non-embryogenic tissue (Bibi et al. 2011), detailed comparison and analysis of regeneration efficiency for both tissues have never been reported. Hence, in this study, we evaluated the shoot organogenesis efficiency for $C$. asiatica tissues cultured on three different optimized shoot induction media (Paramegeetham et al. 2004, Patra et al. 1998, Deshpande et al. 2010). Generally, CE cells cultured on all three media showed a higher shoot organogenesis efficiency than CNE cells (Fig. 2A). The CE cells cultured on MS containing $4.0 \mu \mathrm{M}$ BAP, $2.0 \mu \mathrm{M} \mathrm{Kn}, 0.25 \mu \mathrm{M}$ NAA and $20 \mu \mathrm{M}$ adenine sulphate (Ads) showed the highest shoot organogenesis efficiency (Fig. 2A). These CE 
cells formed compact greenish structure followed by embryo initiation that eventually leads to the formation of shoots (Fig. 2B, C, D, E). Low shoot organogenesis efficiency was recorded for CNE cells cultured in all the three tested
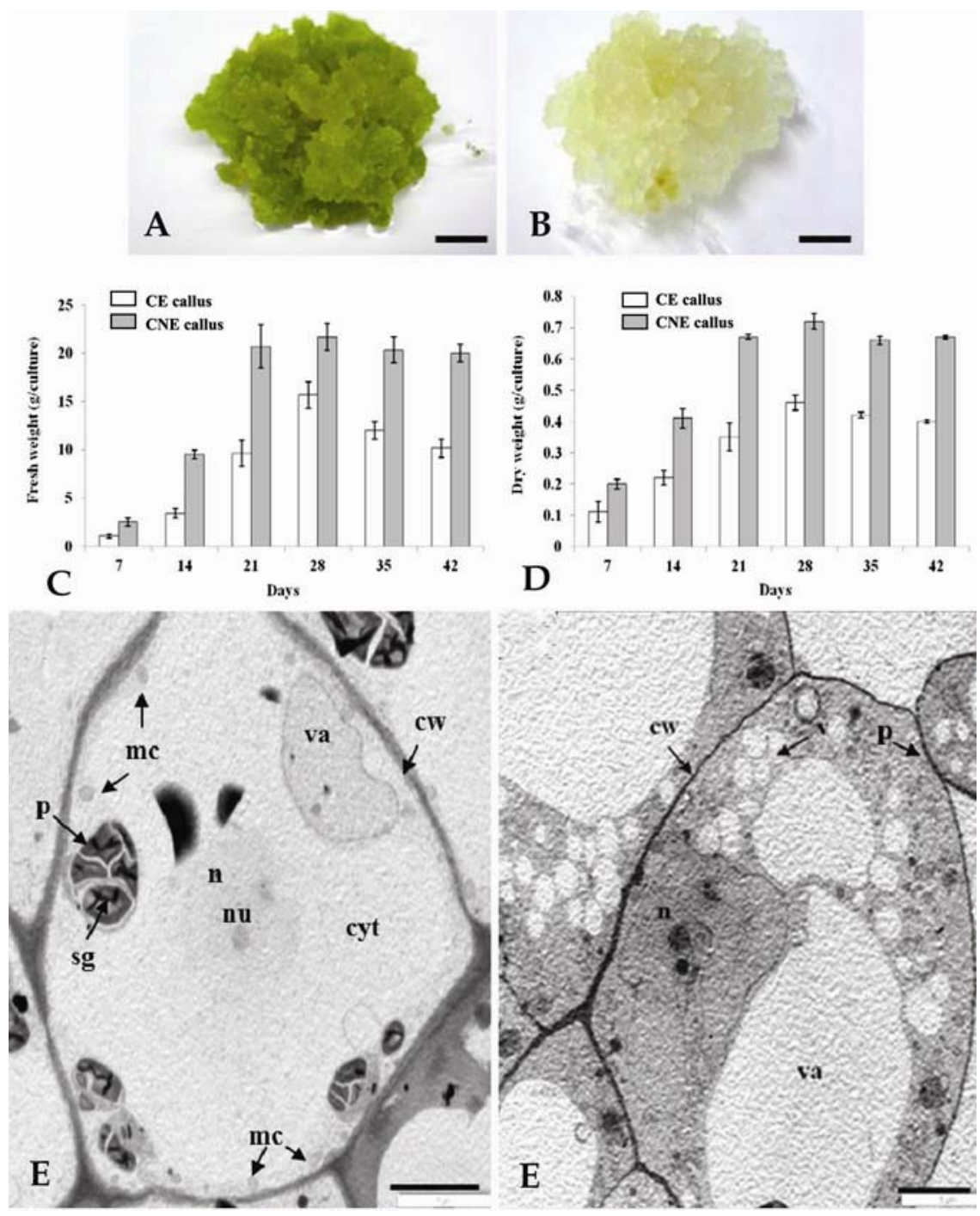

Fig. 1. Growth curve measurement and TEM images of $C$. asiatica calli. (A) CE callus. (B) CNE callus. (C) Fresh weight measurement of C. asiatica calli. (D) Dry weight measurement of C. asiatica calli. The results are the mean standard deviation $( \pm S D)$ of three independent experiments. TEM images of (E) CE callus and (F) CNE callus. cw: cell wall, cyt: cytoplasm, mc: mitochondria, n: nucleus; nu: nucleolus, p: plastid, sg: starch granule, v: vesicle, va: vacuole. Bars A, B: $0.5 \mathrm{~cm}, \mathrm{E}, \mathrm{F}$ : $5 \mu \mathrm{m}$. 
media (Fig. 2A). Clearly, present results indicate that CE cells have much stronger regeneration efficiency than CNE cells. The excised shoots from these cells were cultured on the rooting media for root initiation (Fig. 2F, G, H). Authors observed no significant root initiation differences for shoots derived from either CE or CNE cells. Regenerated plantlets were then transferred and acclimated in the greenhouse (Fig. 4I, J).

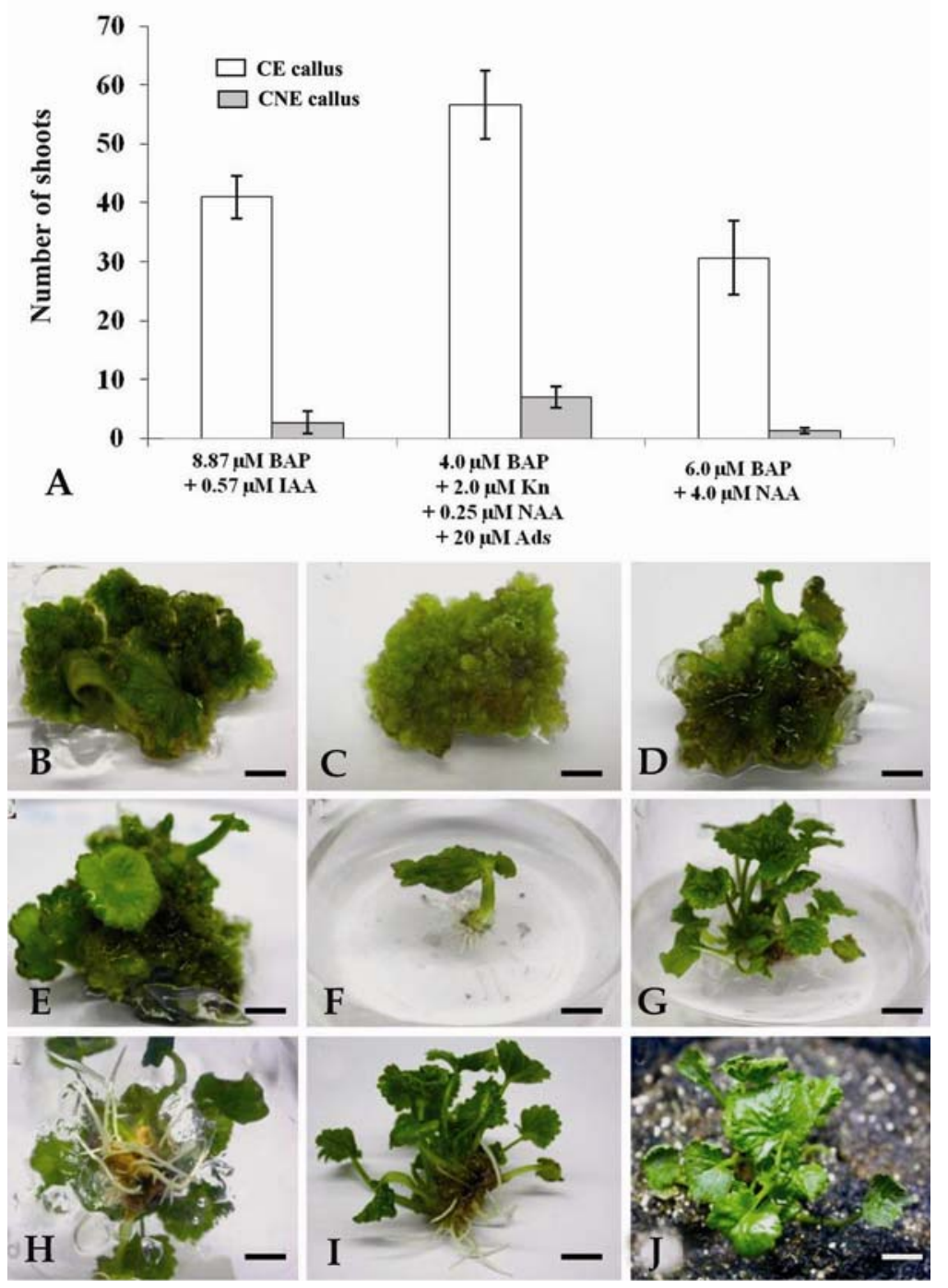

Fig. 2. (A) Shoot organogenesis analysis of C. asiatica calli cultured on different optimized shoot induction MS. For each medium, 15 calli were counted for shoot formation in 3 independent biological replicates. (B) Callus induction from leaf explant. (C) Green compact callus. (D, E) Shoot formation. (F, G, H) Root formation. (I) Regenerated plantlet. (J) In vitro regenerated plantlet of C. asiatica transferred into pot. Bars B-E: $0.5 \mathrm{~cm}, \mathrm{~F}-\mathrm{J}: 1.0 \mathrm{~cm}$. 
Morphological and Physiological Characterization of Embryogenic

\section{Acknowledgement}

The authors like to thank the members of Plant Biotechnology Laboratory for their technical assistance in this study.

\section{References}

Bibi Y, Zia M, Nisa S, Habib D, Waheed A and Chaudhary FM (2011) Regeneration of Centella asiatica plants from non-embryogenic cell lines and evaluation of antibacterial and antifungal properties of regenerated calli and plants. J. Biol. Eng. 5: 13.

Chandra SP, Mahadev MP and Naidu CV (2014) High efficiency adventitious indirect organogenesis and plant regeneration from callus of Centella asiatica L. - An important anti-jaundice medicinal plant. International J. Adv. Res. 2: 1027-1036.

Deshpande HA, Chalse MN and Bhalsing SR (2010) Centella asiatica L.: Plant regeneration through leaf derived callus. J. Herb. Med. Toxicol. 4(2): 119-122.

Lai KS, Abdullah P, Yusoff K and Mahmood M (2011) An efficient protocol for particle bombardment-mediated transformation of Centella asiatica callus. Acta Physiol. Plant. 33: 2547-2552.

Lai KS, Yusoff K and Mahmood M (2012) Heterologous expression of hemagglutininneuraminidase protein from Newcastle disease virus strain AF2240 in Centella asiatica. Acta Biol. Cracov. Bot. 54/1: 7-12.

Marzena P, Ślesak H and Góralski G (2006) Histological and SEM studies on organogenesis in endosperm-derived callus of kiwifruit (Actinida deliciosa cv. Hayward). Acta Biol. Cracov. Bot. 48/2: 97-104.

Namasivayam P (2007) Acquisition of embryogenic competence during somatic embryogenesis. Plant Cell Tiss. \& Org. Cult. 90: 1-8.

Namasivayam P, Skepper J and Hanke D (2006) Identification of a potential structural marker for embryogenic competency in the Brassica napus spp. oleifera embryogenic tissue. Plant Cell Rep. 25: 887-895.

Paramageetham CH, Prasad-babu G and Rao JVS (2004) Somatic embryogenesis in Centella asiatica L. - an important medicinal and neutraceutical plant of India. Plant Cell Tiss. \& Org. Cult. 79: 19-24.

Patra A, Rai B, Rout GR and Das P (1998) Successful plant regeneration from callus cultures of Centella asiatica (Linn.) Urban. Plant Growth Regul. 24: 13-16.

Puigderrajols P, Mir G and Molinas M (2001) Ultrastructure of early secondary embryogenesis by multicellular and unicellular pathways in cork oak (Quercus suber L.). Ann. Bot.,London 87: 179-189.

Tiwari KN, Sharma CN, Tiwari V and Singh BD (2000) Micropropagation of Centella asiatica L., a valuable medicinal herb. Plant Cell Tiss. \& Org. Cult. 63: 179-185. 